\title{
Artes de governo do liberalismo autoritário
}

\section{Government arts of authoritarian liberalism}

\section{Artes de gobierno del liberalismo autoritário}

Amarildo Inácio dos Santos

Universidade Federal da Bahia (Brasil)

CHAMAYOU, Grégoire. A sociedade ingovernável: uma genealogia do liberalismo autoritário. Tradução Letícia Mei. São Paulo: Ubu Editora, 2020.

Grégoire Chamayou é um filósofo francês e sua obra é um estudo realizado nos moldes genealógicos de acordo com Michel Foucault. $\bigcirc$ autor analisa a emergência das artes de governo do liberalismo autoritário. A obra tem 432 páginas e está dividida em seis capítulos. A fim de organizar o texto, a divisão proposta pelo autor apresenta um capítulo por vez.

No capítulo inicial, Chamayou aborda as indisciplinas operárias nos anos 1970 nos Estados Unidos que obrigam o patronato a buscar estratégias para conter a onda de sabotagens e absenteísmo que prejudicava a produção. Os empregadores adotaram a democracia de fábrica convocando os trabalhadores a participar das decisões. Porém, os gestores temiam perder o controle e se viam diante de um dilema. Manter o modelo tradicional de gestão se mostrou contraproducente, pois acarretava o descontentamento dos trabalhadores que não se dobravam à excessiva disciplina. Já promover a autonomia dos operários era perigoso, pois autonomia sempre gera mais demanda por autonomia. Os gestores perceberam que a chave era utilizar o medo. Aquela geração não temia o desemprego em função do estado de bem estar social. Era preciso reintroduzir o medo, pois isso produziria disciplina. Para isso, era necessário produzir insegurança social e a solução encontrada por Nixon, então presidente dos Estados Unidos, foi produzir uma recessão econômica reintroduzindo o medo nos operários e silenciando-os.

No segundo capítulo, o autor analisa a revolução gerencial. O gerencialismo substituiu a administração e produziu uma mudança importante ao dissolver o átomo da propriedade. No gerencialismo, os proprietários não 
têm controle e quem controla não têm a propriedade. Há uma ruptura entre propriedade e controle que desencadeia um problema de governabilidade. Se o gestor não é o proprietário, não se esforçará pela empresa como faria se o fosse. As empresas resolvem o problema do "gestor preguiçoso" atrelando seu interesse ao dos acionistas e oferecendo ações a preços mais atrativos que os do mercado. Ao adquirir ações, os gestores têm interesses pessoais que justificam um esforço maior. Outra estratégia foi manter os gestores sob constante ameaça. Se um gestor não faz o que interessa aos acionistas, outro fará. Surge uma espécie de metacontrole que não deixa opção aos gestores senão fazer o que se espera deles. O valor acionário é utilizado para vigiar a atuação dos gestores, constituindo-se uma tecnologia de governo de condutas. Se o valor das ações cai, o gestor cai.

O terceiro capítulo é dedicado à reação da sociedade à livre iniciativa. O controle gerencial transcende os muros das empresas e alcança os indivíduos em quase todos os seus papeis sociais. $\bigcirc$ modelo empresarial se torna o governo privado da vida orientando, inclusive, desejos e gostos dos consumidores pela publicidade e pelo marketing, exercendo uma dominação estilística maximizada pelas mídias de massa. Porém, o aparente onipotente

2 e onipresente poder do gerencialismo empresarial se vê diante da militância e do ativismo que redirecionam seu foco das instituições públicas para as privadas, pois, as grandes corporações impactam na vida de todos por sua abrangência. Os ativistas e militantes exigem responsabilidade social pelos danos ecológicos oriundos das atividades corporativas. Os liberais veem essas pessoas como uma elite que perdeu o senso de elitismo com a democratização e a difusão do ensino superior. Daí a democracia e a universidade serem vistas como inimigas nessa ótica. Com o surgimento dos ativistas e militantes, a batalha não era mais contra as indisciplinas operárias, mas contra ideias, demandando novas estratégias, novas artes de governo.

No capítulo quatro, o autor escreve que a onda contestatória obrigou as empresas a desenvolverem estratégias de gestão de crises, chamadas de contra-ativismo corporativo, e utilizarem o ativismo contra o ativismo. As empresas queriam saber como pequenos grupos ativistas podiam exercer tanta pressão sobre grandes corporações. Estudaram essas estratégias para poder desmontá-las. Perceberam que a legitimidade dos ativistas era o problema e provinha de instituições socialmente valorizadas como igrejas e universidades. As empresas mudaram o tom assumindo o discurso da responsabilidade social 
e chamando os ativistas ao diálogo e, assim, melhorar a sua imagem. Porém, o diálogo visava converter os interesses dos ativistas aos das empresas. Já que as demandas não podiam ser evitadas, as empresas assumiram uma posição ativista para determinar as decisões. Então, se apropriaram das pautas para governar as demandas ao seu modo.

No capítulo cinco, o autor escreve que a emergência das corporações multinacionais alterou as relações de comércio que se internacionalizaram e demandaram novos regimes jurídicos. Regular o capitalismo global era a questão e essa regulação estatal se tornou um obstáculo. A Organização das Nações Unidas (ONU) também se tornou um empecilho, pois os interesses de países em desenvolvimento (a maioria) se chocavam com o dos países ricos. Assim, era impossível evitar a regulamentação e os países ricos criaram, na Organização para a Cooperação e Desenvolvimento Econômico (OCDE) seu próprio regulamento que apela para a rigidez das leis para assegurar seus interesses, e a sua flexibilidade quando se trata de regular suas atividades. Isso ficou conhecido como soft law, direito flexível. As empresas passaram a transferir para a sociedade a responsabilidade pelos impactos sociais. Se os atingidos por poluição se importam com suas vidas e com a natureza, devem atribuir valor a isso. Assim, emerge o capitalismo verde que investe em publicidade para conscientizar a sociedade sobre a polvição enquanto constrói a ideia de que são as pessoas que polvem. Essa transferência de responsabilidade é uma arte de governar os outros levando-os a gerenciar a si mesmos. As pessoas separam o lixo acreditando que a responsabilidade é apenas sua. As empresas eliminam os custos sobre os rejeitos de sua produção ao mesmo tempo em que transferem a responsabilidade pela polvição.

$\bigcirc$ capítulo seis é dedicado ao argumento neoliberal de que a sociedade se tornou ingovernável por causa da democracia, o que justificaria medidas autoritárias. Ao utilizarem o termo "sociedade ingovernável", os liberais na verdade se referem às atividades corporativas dificultadas por movimentos contestatórios e regulamentações estatais. Atribuem ao estado de bem estar social e aos movimentos sociais a culpa pela crise e argumentam que é preciso desdemocratizar o Estado que deve ser politicamente autoritário e economicamente liberal. Em vez de o Estado regular os mercados, estes é que devem regular o Estado. Mas como desdemocratizar sem pagar o preço político? A resposta é inserir as mudanças aos poucos e a privatização é um exemplo. A amplitude estatal é gradualmente reduzida sem que a população 
perceba imediatamente os impactos em suas vidas, reduzindo as resistências. Sucatear os serviços públicos, limitando orçamentos, também é uma estratégia utilizada, pois reforça o argumento de que os serviços públicos não funcionam. Assim, os direitos vão se tornando mercadoria sem que a população perceba. A privatização opera uma mudança de ethos e racionalidade.

A obra permite pensar a atualidade na qual governos autoritários adotam as estratégias descritas para desdemocratizar o Estado e colocá-lo à serviço do neoliberalismo. Isso impacta na educação brasileira, um exemplo é a reforma do ensino médio que foi umas das primeiras ações do governo Temer. A reforma foi realizada pela Medida Provisória 746, convertida na Lei 13.415 de 2017. Não houve diálogo com pesquisadores, professores e sociedade civil, sinalizando o autoritarismo. A Emenda Constitucional 95 é outro exemplo. $\bigcirc$ congelamento dos gastos públicos sucateará a educação pública, reforçando o discurso de privatização. A escola deve legitimar os arranjos sociais que interessam ao mercado e não problematizálos. A fala de Bolsonaro em sua campanha: "Ninguém quer saber de jovem com senso crítico" sinaliza bem essa racionalidade do liberalismo autoritário. A imposição da Base Nacional Comum Curricular (BNCC) é também exemplar. $\bigcirc$ docu-

4 mento sinaliza a educação que se busca e o sujeito que se quer formar. Um sujeito alinhado à racionalidade neoliberal. Um sujeito empresa de si.

\section{Nota}

$1 \quad O$ presente trabalho foi realizado com apoio da Coordenação de Aperfeiçoamento de Pessoal de Nível Superior (CAPES) - Código de Financiamento 001.

Ms. Amarildo Inácio dos Santos

Universidade Federal da Bahia (Brasil)

Programa de pós-Graduação em Educação

Grupo de Pesquisa: Políticas de Educação na Contemporaneidade

Orcid id: https: / / orcid.org/0000-000 1-9582-9791

E-mail: amarildoinacio.ds@gmail.com

Recebido 21 out. 2020

Aceito 2 nov. 2020 